\title{
Draft of conflict rules angers Congress
}

\section{- Weiss sees backsliding in the Public Health Service - Universities police themselves}

\section{Washington}

THE battle between the research community and the US Congress over conflicts of interest in research seems about to be rejoined. That, at least, seems the purpose of Representative Ted Weiss, chairman of the House of Representatives Government Operations Committee, which this week released an internal draft of proposed federal regulations on conflicts of interest in research, as well as the results of its own three-year investigation of the problem.

The congressional report, citing case studies of improper university and government handling of research conflicts, says that institutions are reluctant to find fault with their own researchers, even retaliating against whistleblowers. The report also says that federal funding agencies, in particular the National Institutes of Health (NIH), have repeatedly ignored problems arising as well as their own principles on conflicts of interest.

The draft federal regulations that the committee has now made public show that the government is planning substantially to weaken the regulations it had earlier proposed, in part because of a backlash from researchers who complained that the rules were unnecessarily intrusive.

The draft regulations, dated 16 July this year, differ from previous versions in that they apply only to clinical trials supported by the Public Health Service (PHS), which includes NIH. Other PHS-supported research will be subject only to whatever rules exist at the institution at which it takes place. An accompanying memorandum by PHS regulation officer John Gallivan explains that the focus on clinical trials arises from "the near-term significance of this kind of research" and its ties to commercial products.

Universities and other research institutions will determine whether conflicts of interest exist among their researchers. "Designated institution officials may approve the ownership or acquisition, by investigators participating in PHS-supported clinical trials, of financial interests in organizations that manufacture, sell or otherwise have property rights in the product under study. But "such interest must be judged unlikely to compromise the design, conduct or reporting of the ... research", say the draft regulations.

Previous versions of the regulations stipulated that researchers "shall not have financial interest" in such organizations un- less the interest "is judged so small as to rule out any significant likelihood" that the outcome of research would be distorted.

In a statement, Weiss attacked the draft PHS regulations as a step in the wrong direction. The regulations "do not suggest the level of commitment by the federal government that will be needed" to resolve problems of the kind documented in his own committee's report, Weiss says. "The net effect of promulgating such regulations would be to maintain the status quo", he argued.

Last year, PHS proposed strict conflictof-interest guidelines to ensure a uniform set of standards at all PHS-supported institutions. But universities protested that compliance would require enormous amounts of paperwork for no clear benefit. PHS retracted the guidelines early this year (Nature 343, 104; 11 January 1990), promising to produce a less onerous set of legally binding regulations. The draft released by Weiss's committee this week is thought to be close to the final rules that will be published later this year.

Weiss is concerned that the new regulations require researchers to disclose their financial holdings only to their own institution's administrators, rather than directly to the federal agencies or the general public. Pointing to the examples of improper and ignored conflict of interest documented in the committee report, one congressional staff-member notes that "these administrators are the same people who are telling us that there is no problem".

The long-awaited congressional report on the scope of the problem documents ten examples of the failure of existing safeguards against conflicts of interest. Some of the cases have already received attention, but others have not previously been made public. Among the cases, the report details the financial holding of researchers studying the efficacy of TPA, the clot-dissolving drug manufactured by Genentech. At least 14 of the researchers involved owned Genentech stock, a fact they had not initially revealed.

The report also notes that although the researchers reported that TPA performed better than its competitor (streptokinase), later independent studies showed that neither drug was substantially superior to the other, and both had dangerous side effects.

Also documented is the case of RetinA, an acne cream that has recently been sold as drug to reverse wrinkling - a claim

\section{Piggy-back ride for an interim Hotol?}

London

BRITISH Aerospace's Hotol spaceplane project, which has been floundering ever since the British government decided to withdraw funding two years ago, may be back in business with a little help from the Soviet Union. A new plan calls for the plane to be carried high into the atmosphere riding piggy-back on an Antonov An-225 - the world's largest aircraft.

Hotol was conceived as a revolutionary unmanned reusable space launch vehicle, capable of taking off from a horizontal runway powered by an air-breathing rocket engine. But the engine's development costs, accounting for more than half of the $£ 6,000$ million project, have proved prohibitive.

British Aerospace is now planning to leave the development of the engine until later. A six-month study with the Soviet aviation ministry will see if Hotol could be lauched from the back of the Soviet Antonov An-225 transport aircraft and powered into space by conventional rockets, perhaps supplied by the Soviets.

The An-225 was designed to carry large structures on its back, and has been used for transporting the Soviet space shuttle. But to launch Hotol into space, the An-225 may need an engine upgrade, to carry the heavy aircraft and its payload to about 9 km altitude. British Aerospace calls the new plan the 'interim Hotol', and hopes that the original concept, complete with the air-breathing engine, can be developed at a later date.

If successful, the interim system could offer 7-tonne payload launches for $\$ 10-12$ million by early next century about a quarter of the price of launches on the latest version of the European Space Agency (ESA)'s Ariane rocket. A British Aerospace spokesman says that ESA and other agencies will need cheap replacements for existing launchers, to put the many planned Earth observation and communications satellites into orbit. Peter Aldhous

based on research published in the Journal of the American Medical Association in 1988. After other scientists disputed Retin-A's effectiveness as an antiageing drug, the original researchers admitted that the J. Am. med. Ass. study had not been double-blind.

Investigations by the Weiss committee are said now to have revealed that several of the original researchers had served as spokesmen for Johnson \& Johnson, Retin-A's manufacturer. Others had received Johnson \& Johnson honoraria and research grants. A recent NIH conference on the ageing effect of light concluded that the safety and efficacy of Retin-A has not been established, the report says.

Christopher Anderson 